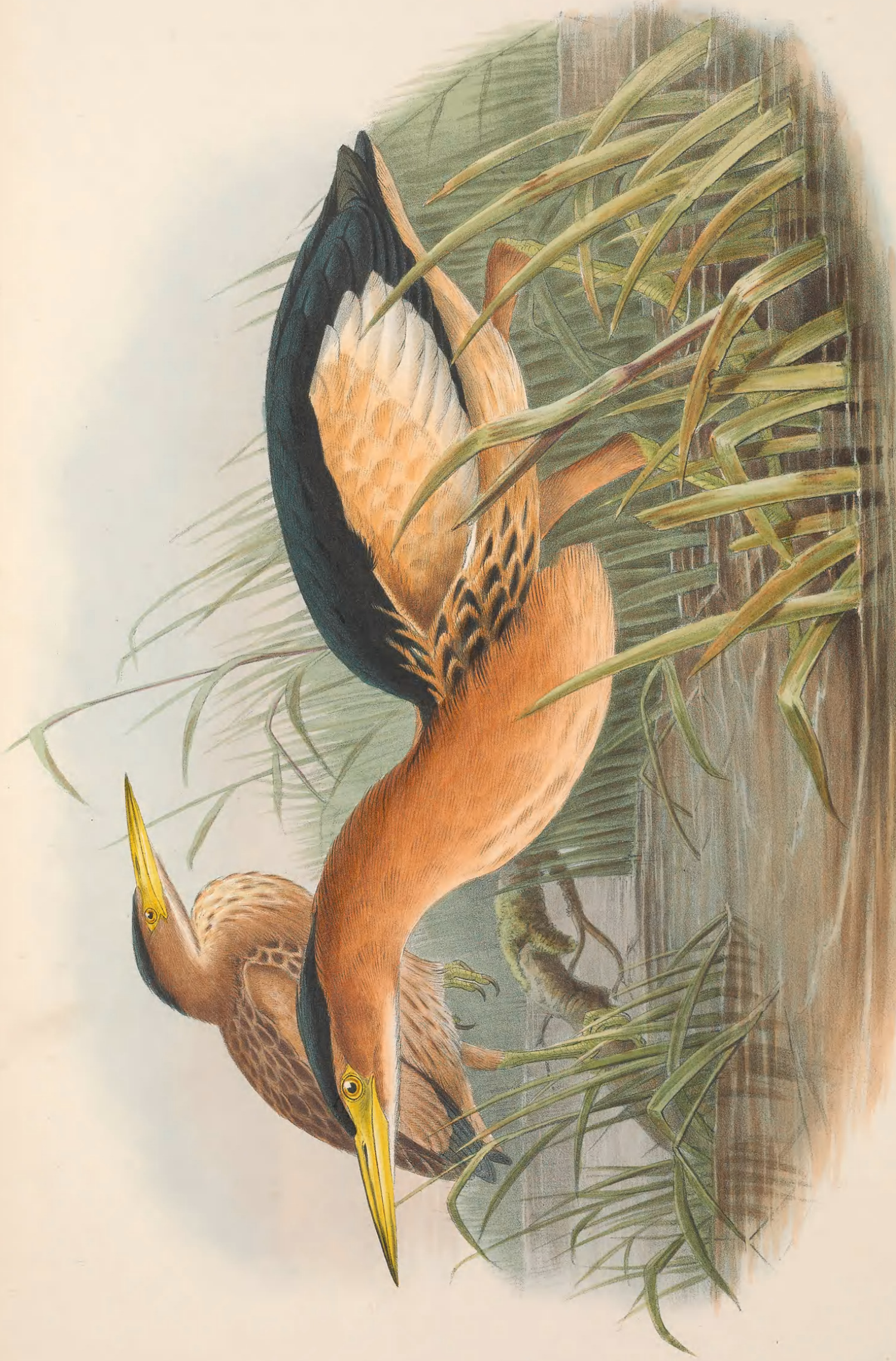

 


\section{ARDETTA MINUTA.}

\section{Little Bittern.}

Ardea minuta, Linn. Syst. Nat., tom. i. p. 240.

danubialis, Gmel. edit. Linn. Syst. Nat., tom. i. p. 637.

Botaurus minutus, Boie, Isis, 1822, p. 559.

pusillus, Brehm, Vög. Deutschl., p. 598.

Ardeola minuta, Bonap. Geog. and Comp. List of Birds of Eur. and N. Amer., p. 48.

Cancrophagus minutus, Kaup, Natiirl. Syst., p. 42.

Butor minutus, Swains. Class. of Birds, vol. ii. p. 354.

THE Little Bittern, being a very shy and recluse bird, it is probable that many more examples may have come to England than have been detected; however this may be, it has been killed in sufficient numbers, both in this country and in Ireland, to show that it is not one of the rarest of our British birds. Most of these have been obtained in the spring, just prior to the breeding-season, a period of the year when birds become restless and are prompted to wander, and probably have been individuals which, during their passage from south to north, have been driven out of their course in a westerly direction, when, as a natural consequence, they would strike the British shores, and gladly seek rest by alighting thereon. If under these circumstances two or more of opposite*sexes were to meet, there is no reason why they should not breed and spend the summer among our marshes and fluviatile districts, as the Great Bittern used to do; as yet, however, I believe neither eggs nor very young birds have been procured. That at least some of the specimens which have been obtained were birds which had been driven out of their intended course is evident from the following notes, communicated to me by Mr. Gatcombe :- "Early in May 1865, a pair of Little Bitterns were seen in the neighbourhood of Plymouth, one of which was caught by some boys, who said it was entangled in a bramble bush by the side of a stream. It was a male in fine plumage ; its companion flew away." In another note Mr. Gatcombe says, " it may interest you to know that a Little Bittern was obtained at the fishing-village of Beer, near Seaton, on the coast of Devon, on the 20th of April, 1869. It was seen by some fishermen to alight in a boat lying on the beach, and was taken out of it in a most exhausted state; and I know of several other examples which have been picked up in the same state on our coast."

Besides the above, instances are on record of the occurrence of the Little Bittern in Somersetshire, Herefordshire, Shropshire, South Wales, Dorsetshire, Hampshire, Middlesex, Norfolk, Cambridgeshire, Yorkshire, Northumberland, and, lastly, in Cornwall, as detailed in the following notes from my friend E. H. Rodd, Esq., of Penzance :- “ June 14, 1866. I saw yesterday a very beautiful specimen of a male Little Bittern in the highest development of plumage. It was killed at the large pool at Trescoe, one of the Scilly Islands; its weight was exactly three ounces, and its ruff quite as large in proportion to the bird as that of the Bittern." "April 12, 1867. An adult male Little Bittern, in fine plumage, like the one from Mr. Smith's grounds in Scilly, was brought to me yesterday. It was killed not far from St. Michael's Mount; like the former it weighed three ounces."

Mr. T. White, Taxidermist, of Bath Road, Cheltenham, wrote November 20, 1867 :- "I have a Little Bittern, killed last winter within a mile of this town, at a pond full of dead rushes \&c. There were three more, but I could not succeed in killing either of them; they go off in the daytime, but come back at dusk."

Apart from the British Islands the Little Bittern ranges in summer over all the central and southern parts of Europe, and in winter is probably as extensively spread over Africa. Its occurrence in India is very doubtful; for although Dr. Leith Adams includes it in his list of the birds of that country, Mr. Jerdon thinks it likely that he has mistaken the Ardetta sinensis for our species.

Speaking of the bird in Norfolk, Mr. Stevenson says:- "No doubt, from time immemorial, the Little Bittern has occasionally sought shelter in the luxuriant herbage of the "Broad"-district, nor is it at all improbable that it may even have remained with us at times and bred, having been found in pairs during the summer months, and, in one instance, a perfect egg was taken from a female killed near Lowestoft. Its skulking habits, however, and the almost impenetrable nature of the swamps it frequents, render its detection, except by the merest accident, extremely improbable."

The situations described by Mr. Stevenson are precisely those which the bird frequents in every country in which it is found. During the spring it frequently perches on trees; and Selby says that its usual 
position, when at rest, is that of sitting upon the whole length of the tarsi, with the neck bent, the head thrown back, and the bill pointing almost perpendicularly upwards.

"It is a matter of surprise," says Meyer, "how the Little Bittern puts in practice one of its habits, namely that of climbing or running up and down a perpendicular branch of a tree with as much ease as if it walked on the ground. The necessity of placing its feet in a line makes the circumstance unavoidable of crossing its legs at every step, while the formation of its feet is apparently adapted only for the purpose of wading. The length and pliability of the toes and the arched and sharply-pointed claws materially aid the bird in retaining its hold." This remarkable habit is fully confirmed by the following note, with which Mr. C. Buxton has favoured me:- "Fox Warren, Cobham. Dec. 15, 1862. I have two Little Bitterns alive. Their ways and attitudes are the strangest I ever saw. They live entirely on the boughs of a rose-tree that creeps up the wall of the house. They never wade, but evidently only have the idea of hanging-on and striking at their prey as it passes. I shall be happy to lend them to you if you care to watch them; they would live in a basket, and only require a little raw meat. Nobody can help laughing who sees them for the first time, with their beaks pointed to heaven, their eyes peering out at right angles, and their legs straddled out."

“The Little Bittern," continues Meyer, " is very artful in keeping itself out of sight, and also in deceiving the greater number of its enemies, when in an unsheltered spot, by placing itself in a stiff unnatural position when it perceives the approach of danger, in which it remains so immovable, and for so long a time, that, when it is obliged at last to take wing, it flies up with such unexpected noise that the sportsman is generally too much taken by surprise to avail himself of the opportunity of firing until the bird has attained too great a distance to be shot; and when concealed among reeds, rushes, or herbage, it is with the greatest difficulty that it is made to start; and to effect this purpose frequently requires much caution and perseverance. The best time to get a sight of the bird is towards the evening, owing to its habit of coming forth at that time; but, to reach unperceived a hiding-place for the purpose of lying in wait, the greatest caution is required when approaching places supposed to be frequented by it.

"The flight of the Little Bittern is different from that of others of its family, being performed with stronger and quicker motions of the wings. It does not fly high in the air during the day, but only high enongh, in general, to clear the vegetation among which it resides. In the act of taking flight, it flutters quickly with its wings; but when alighting, it throws itself, as it were, to the earth, only breaking its fall when close to the ground by expanding the wings."

The food of the Little Bittern naturally consists of the objects which are so abundant in the swampy places it frequents-namely, small fishes, young frogs, newts, aquatic insects, worms, and mollusca of various kinds. It breeds among the rushes, the nest being placed on hummocks in the marshes, a little above the usual rise of the water, and in some instances on the overhanging boughs of a tree; it is said that a few have also been found in bushes about three feet from the ground; it is a large and shapeless structure, composed of broken reeds, grass, and other similar materials. The eggs are five or six in number, white, tinged with very pale blue, an inch and five twelfths in length by an inch and a twelfth in breadth. Their incubation occupies sixteen or seventeen days.

The male is stated by Vieillot to emit, when alarmed, a loud barking cry, much resembling the barking of a dog when heard at a distance; and in a communication sent to the 'Zoologist' in 1849 by the Rev. H. T. Frere it is thus described:- " On two or three successive nights, when sailing on the broad, we heard a noise in the marsh at the side resembling the bark of a dog, or more nearly the grunt a paviour gives when dropping his rammer. Though all the party were tolerably well acquainted with the notes of the marshbirds, this was a novelty to us. A marshman, however, recognized it as the note of the Little Bittern, one of which he had shot some thirty years before."

"With reference to the somewhat puzzling plumage of this species," says Mr. Stevenson, "Messrs. Gurney and Fisher remark, "from an inspection of the specimens obtained from time to time in the Norfolk district, we incline to the opinion that, if the females of this species ultimately arrive at a plumage similar to that of the adult males, as is asserted by modern naturalists, it is only at a much more advanced period than that at which the same plumage is assumed by the latter; and it appears quite certain that the female in the supposed immature plumage pairs with the adult male.'”

The figures in the accompanying Plate, which are of the natural size, will show the ordinary difference in the colouring of the sexes. Owing to the length and looseness of the plumage, one would have supposed that the male at least would weigh nearly double the weight which Mr. Rodd has stated (three ounces). 


\section{$2 \mathrm{BHL}$ Biodiversity Heritage Library}

Gould, John. 1873. "Little Bittern, Ardetta minuta [PI. 29]." The birds of Great Britain 4, -. https://doi.org/10.5962/p.323988.

View This Item Online: https://www.biodiversitylibrary.org/item/221609

DOI: https://doi.org/10.5962/p.323988

Permalink: https://www.biodiversitylibrary.org/partpdf/323988

\section{Holding Institution}

Smithsonian Libraries

\section{Sponsored by}

Biodiversity Heritage Library

\section{Copyright \& Reuse}

Copyright Status: Public domain. The BHL considers that this work is no longer under copyright protection.

This document was created from content at the Biodiversity Heritage Library, the world's largest open access digital library for biodiversity literature and archives. Visit BHL at https://www.biodiversitylibrary.org. 